Article

\title{
Linking FOMO and Smartphone Use to Social Media Brand Communities
}

\author{
Oseyenbhin Sunday Osemeahon * (10) and Mary Agoyi
}

Management Information Systems Department, School of Applied Sciences, Cyprus International University, 99258 Nicosia, Turkey; magoyi@ciu.edu.tr

* Correspondence: ose.sunday@gmail.com

Received: 15 January 2020; Accepted: 6 March 2020; Published: 11 March 2020

\begin{abstract}
Social media brand communities provide firms with the necessary apparatus to develop and maintain relationships. This study explores the effect of fear of missing out (FOMO) and smartphone use on consumer engagement in social media brand communities, which the study hypothesizes to affect consumer loyalty. Data from 279 social media brand community (SMBC) participants were analyzed. Findings reveal that both fear of missing out and smartphone use influence consumer engagement, which in turn influences consumer loyalty in social media brand communities. Furthermore, smartphone use was found to mediate the impact of fear of missing out on consumer engagement.
\end{abstract}

Keywords: social media brand communities; FOMO; consumer engagement

\section{Introduction}

The need to engage with the target audience motivates brands to maintain an active online presence on social media. Over one-third of the world's population is found engaging in social media today $[1,2]$. These engagements are characterized by individual networks as well as groups and corporate communities [1,2]. A litany of evidence exists to support the growth of online brand communities on different social media platforms [3-7]. This is because they present brand-building opportunities in reaching out and building relationships with consumers. Most importantly, these online communities offer heterogeneity relative to geography and audience [8]. From the corporate branding literature, Lui et al. (2018b) concluded that these developments pioneered social media brand communities (SMBCs). SMBCs present brands with relevant engagement opportunities that support brands in building and maintaining relationships with their audience [6,7].

However, the challenge for brands to remain agile toward achieving effective consumer engagement in SMBCs remains an overarching one, especially if they have to maintain constituency and community loyalty [6,7]. Consumer engagement in online communities is essential, especially in sustaining the values and opportunities of these communities [9].

Consumer engagement (CE) strategies in SMBCs requires an understanding of engagement behavior (i.e., 'liking', commenting and retransmitting content). Particularly, Islam et al. (2018) emphasized the role of the psychological drivers of user participation. For instance, among age cohorts, Tefertiller, Maxwell and Morris (2019) highlighted peer influence and the fear of missing out (FOMO) as psychological influencers of engagement behavior of individuals online. FOMO describes a pervasive feeling experienced by an individual, where they feel left out on activities experienced by their peers [10]. Tefertiller et al. (2019) established a positive nexus between FOMO and user engagement on online platforms. In addition, several studies further acknowledge the fact that mobile device use facilitates the propagation of FOMO online [11,12]. Because consumers engage more in social media via mobile devices like smartphones [4], there seems to be a growth in the prevalence of 
the phenomenon of FOMO across online communities [13]. Yet, it is surprising few studies have paid attention to the actual role of FOMO in SMBCs via consumer engagement. It is essential to have more insight into drivers of consumer engagement, which in turn generates loyalty to the communities, as several active online communities have failed to retain their members and have become 'online ghost towns' [14]. The loyalty of these SMBC members goes a long way in determining the sustainability of the community [15].

In an attempt to enrich existing literature to ensure the sustainability of SMBCs, this study aims at exploring the influence of the fear of missing out (FOMO) and smartphone use (SPU) on consumer engagement (CU) to drive loyalty (L) to social media brand communities (SMBCs).

\section{Theoretical Foundations and Hypothesis}

Self Determination Theory is one of the most common theories used in the conceptualization of fear of missing out (FOMO) $[10,11,16]$. Self Determination Theory deals with the inherent needs and motivations of people. In relation to FOMO, a vital driver for intrinsic satisfaction is the need for socialization, social relatedness and human connection [11], while smartphones have proven to be an effective tool in meeting psychological needs $[17,18]$. Being anxious because of an unmet social-related desire can be seen as FOMO in the Self Determination Theory framework $[10,19]$. This means that individuals with high unmet social relatedness needs experience FOMO and may engage in social networking technology in order to be current with their social network. Using Self Determination Theory, FOMO brings about an urge in the mind of consumers to take part in SMBC activities with the help of smartphones, as the portability of smartphones enhances the innate mobility needs of humans [18].

A consumer's loyalty is seen by his/her intention to stick with an SMBC as a primary choice. Loyal SMBC members are important to firms because they are cheaper to maintain compared to acquiring new prospects, and loyal members pay less attention to alternatives [20-22]. In particular, convincing members to remain loyal to an SMBC is a formidable challenge [23]. Social Cognitive Theory suggests that individuals possess a system of self-beliefs that enables them to engage and develop loyalty to an online community [24]. Using Social Cognitive Theory when consumers engage in an $\mathrm{SMBC}$, they tend to exchange ideas, get and send referrals and desire to conform to the anticipation of other community members, which will make them generate loyalty to that community.

\subsection{Fear of Missing Out on Consumer Engagement and Smartphone Use}

FOMO is a situation in which an individual is anxious or worried about missing out on an experience that is socially interactive [10]. Various studies have shown the superior persuasive effect FOMO has on influencing the behaviors of individuals towards engaging in online activities [10,25-29]. The consumer-based brand equity model, and its extended model called the consumer based brand equity pyramid [30-32], suggest that when consumers' desired experiences (e.g., social interactions between social media users) are linked to a brand, they engage not only with the brand but also with other fellow users of the brand. FOMO drives individuals to participate in social media activities (i.e., consumer engagement) since consumer engagement is also a social media activity that includes posting, reacting, sharing and commenting on online brand related content by consumers in an SMBC [4,32,33]. Thus, this study hypothesized the following:

Hypothesis 1. (H1). FOMO positively influences consumer engagement in SMBCs.

FOMO is a form of anxiety that is a possible contributor to increase the use of digital technology [34]. The anxiety generated by FOMO brings about a persuasive urge that influences individuals to be in constant use of their smartphones [35]. Apprehension from FOMO brings missing pleasurable experiences, with the need to constantly stay connected with members of one's social network [19], and the ubiquitous presence of smartphones causes the boundaries existing between an individual and 
the world to disappear, interlinking individuals with their social network [12,36]. Thus, the following is hypothesized:

Hypothesis 2. (H2). FOMO positively influences SPU.

\subsection{Smartphone Use (SPU) and Consumer Engagement}

Smartphones contain functionalities that enable its users to perform actions that can be done mostly using personal computers [37]. Social media applications on smartphones have created social bonding between social media users on SMBC due to the possibility of constant communication and engagement with other individuals on social media [38]. Smartphone use has become a norm in recent times and its highly dependent on individuals having the sense of belongingness in a social media community [39,40]. Thus, this study hypothesized the following:

Hypothesis 3. (H3). SPU positively influences consumer engagement in SMBCs.

\subsection{Consumer Engagement on Loyalty}

Consumer loyalty has a vital impact on brand performance, which deals with consumers' attachment and commitment to a brand [41]. Consumer loyalty towards an SMBC will increase while the consumer constantly engages in the community [42]. Social media platforms have several engaging functionalities that brands harness in fostering a relationship between consumers and SMBCs [3]. Consumers engaging in SMBCs is a key way to trigger, build or foster emotional bonds to render increased consumer loyalty to the community $[3,21]$. Consumer engagement behaviors in SMBCs can be characterized by sharing, advocating, socializing and co-developing in an SMBC, which is a significant, non-transactional pathway to SMBC loyalty $[43,44]$. Thus, this study posits the following:

Hypothesis 4. (H4). Consumer engagement SMBCs will lead to SMBC loyalty.

\subsection{SPU as a Mediator}

It is expected that a higher propensity of FOMO in consumers may increase the rate of smartphone use in order to access and engage in SMBCs. This can be attributed to smartphone functionalities that enable individuals to perform online social networking tasks, being that FOMO is a persuasive effect that makes individuals engage in online social interactive activities [12,28]. FOMO deals with worries generated due to restricted access to online engaging activities, and smartphone applications grants that access $[25,45,46]$. Therefore, this study hypothesized the following:

Hypothesis 5. (H5). SPU will mediate the relationship between FOMO and consumer engagement in SMBCs.

\section{Research Methodology}

The study selected Facebook as the research context because Facebook is a social network platform that has overwhelming popularity and offers abundant and diverse examples of SMBCs [47,48]. In line with other literature $[49,50]$, the target was not only a single SMBC, but rather a more general approach of members of brand-initiated SMBCs (i.e., not consumer-initiated) in which the participants were instructed to refer to the SMBC to which they belonged. Purposive and snowball sampling methods were used in obtaining respondents for the study. Precisely, for purposive sampling, the criterion for participation was being a member of one or more SMBCs on Facebook. In using snowball sampling, 
the respondents were asked to recommend other potential participants that would meet the benchmark for participation.

The respondents were asked at the beginning of the questionnaire to recall their most vital and followed brand(s) on Facebook before answering the questions. In making sure the chosen SMBCs fit into the criteria of this study, the authors visited and checked each chosen SMBC after the questionnaire collection. Then, the responses were dropped if the chosen SMBCs did not meet the following criteria: (1) the SMBC page allowed comments; (2) members of the community could share experiences about products of the brand with others; and (3) there was release of updated information about the product or the brand. After 3 weeks of data collection, 345 answers were obtained in which 297 responses were valid and used for the analysis of this study. Male respondents were $171(57.6 \%)$ while the female respondents were $126(42.4 \%)$.

\subsection{Measurement Scales}

The items measuring the constructs in the model were adopted from existing studies and measured by using a five-point Likert scale with an endpoint of 1 as strongly disagree and 5 as strongly agree Peer communication, fear of missing out [10], smartphone use [51], consumer engagement [52], and SMBC loyalty were adapted from authors in [42,53]. The measurement items are displayed in Appendix A.

\subsection{Data Analysis and Results}

The study used SmartPLS version 3 in analyzing the collected data and testing the proposed model. The study adopted the PLS-SEM technique because PLS is best suited for exploratory studies with new variables [54]. CE is a developing variable in marketing and with no consensus in its definition $[4,55]$. Also, models with small samples are analyzed best with PLS, which is also the case in the current study.

Internal consistency reliability of the items was assessed via Cronbach's $\alpha$. It is recommended that the internal consistency or reliability of each construct should be greater or equal to 0.70 [56]. The results showed the $\alpha$ value of each construct achieving a floor criterion of 0.7 , except for a problematic item from consumer engagement, which was removed from further analysis. Thus, the data in this study were regarded as appropriate for the factor analysis to proceed. The reliability outputs of the measured items are displayed in Table 1.

Table 1. Measures and Factor Loadings.

\begin{tabular}{|c|c|c|c|c|}
\hline Construct & Factor Loading & $\begin{array}{c}\text { Cronbach's Alpha } \\
(\alpha)\end{array}$ & $\begin{array}{l}\text { Composite } \\
\text { Reliability }\end{array}$ & $\begin{array}{l}\text { Average Variance } \\
\text { Extracted (AVE) }\end{array}$ \\
\hline \multirow{4}{*}{$\mathrm{L}$} & 0.905 & \multirow{4}{*}{0.897} & \multirow{4}{*}{0.897} & \multirow{4}{*}{0.687} \\
\hline & 0.914 & & & \\
\hline & 0.712 & & & \\
\hline & 0.767 & & & \\
\hline \multirow{4}{*}{$\mathrm{CE}$} & 0.881 & \multirow{4}{*}{0.891} & \multirow{5}{*}{0.892} & \multirow{5}{*}{0.735} \\
\hline & 0.848 & & & \\
\hline & 0.612 & & & \\
\hline & 0.922 & & & \\
\hline \multirow{3}{*}{ FOMO } & 0.935 & \multirow{3}{*}{0.928} & & \\
\hline & 0.893 & & \multirow[t]{2}{*}{0.929} & \multirow[t]{2}{*}{0.768} \\
\hline & $\begin{array}{l}0.915 \\
0.751\end{array}$ & & & \\
\hline \multirow{4}{*}{ SPU } & 0.932 & \multirow{4}{*}{0.890} & \multirow{4}{*}{0.890} & \multirow{4}{*}{0.672} \\
\hline & 0.801 & & & \\
\hline & 0.816 & & & \\
\hline & 0.713 & & & \\
\hline
\end{tabular}

The convergent validity aimed at assessing the degree of relatedness among the theoretically similar constructs was measured by testing factor loadings $(\lambda)$, average variance extracted (AVE), and 
composite reliability (CR). Cronbach's $\alpha$ values should be greater than 0.70 , AVE accepted values should be more than 0.50 , and CR values of the study constructs should be greater than or equal to $0.70[56,57]$. As reported in Table 1 the construct values of AVE, CR and factor loading $(\lambda)$ of the items satisfied the aforementioned tests, establishing the convergent validity of the survey instrument and denoting acceptable convergent validity.

Discrimination validity is established when the AVE is larger than all correlations with other constructs [57]. As displayed in Table 2, the diagonal elements are the square root of the AVEs (in bold), all of which were found to be greater than the correlation coefficients with other constructs. Thus, the general results showed satisfying discriminant validity.

Table 2. Discriminant Validity.

\begin{tabular}{ccccc}
\hline & BL & CE & FOMO & SPU \\
\hline L & 0.829 & & & \\
CE & 0.551 & 0.857 & & \\
FOMO & 0.519 & 0.401 & 0.877 & \\
SPU & 0.540 & 0.554 & 0.412 & 0.819 \\
\hline
\end{tabular}

\subsection{Common Method Bias}

Harman's one-factor test was deployed in ascertaining that common method bias was avoided in the study. Its of the opinion of scholars that common method bias exist, if one factor is responsible for the bulk of covariance among the measures [4,58]. More than one factor was seen to emerge in the result, with the highest level of covariance of one factor explained at $44.04 \%$. This shows that the indicators could not be accounted for by any single latent variable.

\subsection{Structural Model Analysis}

The results retrieved in testing the various hypotheses are displayed in Figure 1. In achieving this, the study examined the original coefficients $(\beta)$, p-values of the structural model and significance between the independent and dependent constructs. Figure 1 displays the various relationships between the adopted constructs. As shown, a positive relationship existed between all the constructs. Hypothesis testing was deployed to further analyze the various relationships. Further summary of the results is shown in Table 3.

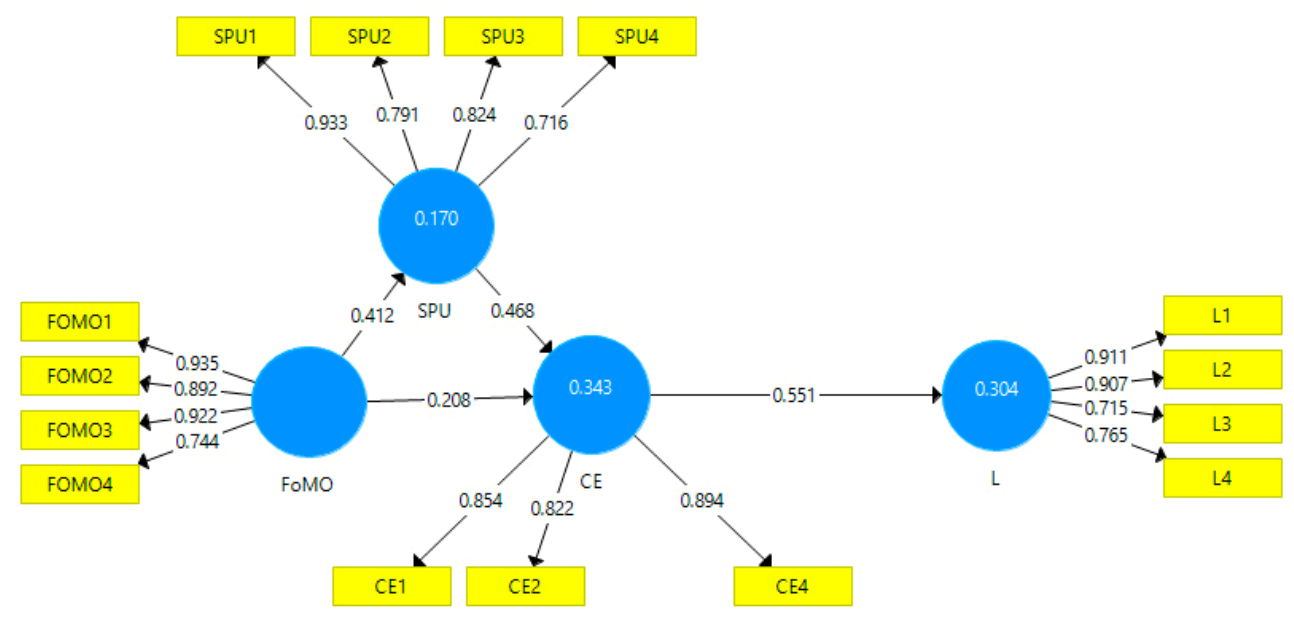

Figure 1. Path analysis. 
Table 3. Summary of Hypotheses Test Results.

\begin{tabular}{llll}
\hline & Coefficient $(\beta)$ & T Statistics & P Values \\
\hline CE $->$ L & 0.551 & 8.384 & 0.000 \\
FOMO -> CE & 0.208 & 2.762 & 0.006 \\
FOMO -> SPU & 0.412 & 5.977 & 0.000 \\
SPU - CE & 0.468 & 6.884 & 0.000 \\
Indirect Effect & & \\
FOMO -> SPU -> CE & 0.193 & 4.721 & 0.000 \\
\hline & Note: $^{* * \prime}=\mathrm{p}<0.05 ;^{\text {(**) }}=\mathrm{p}<0.01$.
\end{tabular}

FOMO maintained its stand with previous social media studies showing its effect in driving individuals to participate in social media activities $[16,27]$ by having a positive and significant influence on $\mathrm{CE}$ in SMBC (H1; $\beta=0.208, \mathrm{p}<0.006)$. In line with [32], when rewarding learning activities occur on a social media platform, the group members will have an urge to participate with their peers.

A positive and significant relationship also existed between FOMO and SPU (H2; $\beta=0.412, p$ $<0.000)$. This result is in sync with the Self Determination Theory $[17,18]$ portraying FOMO as a motivating factor $[10,25]$ that will create a desire in individuals to constantly access their smartphones.

CE proved to have a positive and significant relationship with $\mathrm{L}(\mathrm{H} 4 ; \beta=0.551, \mathrm{p}<0.000)$. This result is in line with other literature, outlining CE as a strategy that secures the loyalty of consumers to an online community [59-61].

The results show SPU mediated the relationship between FOMO and CE (H5 $\beta=0.193, \rho<0.000$ ). This is in line with literature that labelled smartphone to be a valuable asset in providing access to social media $[25,45,46]$.

Thus, all hypotheses were supported. These results indicated that $\mathrm{H} 1, \mathrm{H} 2, \mathrm{H} 3, \mathrm{H} 4$, and $\mathrm{H} 5$ are useful and significant to determine the relationship among the role of fear of missing out, smartphone use, consumer engagement and loyalty to a social media brand community.

\section{Contribution}

Given the limited studies in the sustainability of SMBCs, the current research used Self Determination Theory and Social Cognitive Theory to examine factors that promote consumer engagement in SMBCs in order to generate loyalty of community members. First, the research defined, conceptualized and empirically measured key psychological and technological (FOMO and SPU) antecedents that lead to CE in generating L. Secondly, the study showed that FOMO can be applied in the online brand community context, as both the hypotheses development and results of the study proved a high level of FOMO increased CE in SMBCs. The study also showed smartphone as an essential tool not just in leading to CE but also in mediating the link between FOMO and CE in SMBCs. Lastly, the study confirmed the effect of $\mathrm{CE}$ in online brand communities was also applicable in SMBCs when it came to generating consumer loyalty to SMBCs.

In summary, this study has contributed to online branding literature, as it shows conceptual and empirical evidence of how trust in online brand communities can be generated in order to ensure the sustainability of the community in remaining active and maintaining its members.

\section{Theoretical Implications}

The current research brings novel insights into the existing SMBCs and specifically consumer engagement literature in several ways. First, the study empirically validated the conceptually rich consumer-brand engagement concept, thereby addressing the vacuum pointed out by prior scholars in this domain [62-64]. In effectively addressing this issue, a hypothesized model was formulated and empirically tested involving potent CE antecedents, namely FOMO and SPU, while loyalty to SMBC was the consequence. Results from the study affirmed that FOMO and SPU significantly drove $\mathrm{CE}$ in SMBC. Subsequently, these findings highlight the importance of FOMO and smartphones as 
psychological and technological drivers of consumer engagement in SMBCs, which improves the understanding of the academicians regarding consumer engagement antecedents in SMBCs. Secondly, results from this study lend strong evidence to the vitality of SPU as a mediator between FOMO and $\mathrm{CE}$, thereby extending the knowledge about Self Determination Theory. The significance of this finding is raised manifold, as it provides cues for the possible inclusion of smartphone use in the conceptually direct linkage between FOMO and CE in SMBC. Accordingly, the mediating effect of SPU supports the notion that FOMO acts as a driving factor that can make consumers participate in SMBC activities, thus substantiating the theoretical underpinnings of consumer behaviours.

\section{Managerial Implications}

The purpose of this study was to give better insight into SMBCs by investigating relationships between FOMO, SPU and CE leading to L, and possible mediation from SPU between FOMO and CE in SMBC. From the results derived, all hypothesized relationships examined in the study were supported.

This study found that FOMO led to CE in SMBC. This finding is in accordance with Self Determination Theory, as consumers' quests in finding satisfaction through social connections lead them to engage in SMBCs. To the best of our knowledge, this study is the first to show these findings. This result also confirms previous works emphasizing the trending impact of FOMO in influencing the behaviors of individuals towards engaging in online social networks [16,28,65-67]. In modeling marketing strategies to build up consumer engagement, organizations and brand marketers should focus on giving frequent, interesting and interactive updates on their SMBCs to make consumers optimistic in looking forward to participating in it.

The path analysis results obtained show that smartphones are not just digital gadgets for browsing, but also an effective engagement tool that enhances consumer engagements in SMBCs. SPU also mediated the relationship between FOMO and CE. Also, to the best of our knowledge, this study is the first to show these findings. The result from SPU is in line with [38], which shows how beneficial smartphones are in facilitating consumers in transitioning to social media communities, especially with its mobility features enabling interactions with no space constraint $[67,68]$. This brings more confirmation and light to existing SMBC literature [4] and organizations in fostering customer relationship strategies by giving attention to phone social media applications, as consumers have proven to be inclined in using smartphones in accessing their SMBCs.

As shown in other consumer engagement studies [3,21], CE had a positive influence on consumer loyalty to an SMBC. From the lens of Social Cognitive Theory, this implies that consumers become more loyal to an SMBC as they keep on engaging in the community. This result lays more emphasis on the importance of online brand marketers to constantly keep their SMBCs active and interactive so as to engage their consumers, as results from this study have shown this strategy to be an effective means in making sure consumers remain loyal to their community and, in essence, secure an active and sustainable community able to withstand the test of time.

\section{Limitations and Further Research Directions}

Despite having encouraging results and interesting implications in this study, there were some limitations, suggesting directions for further research. The current study did not focus on a particular brand or brand community, giving room for future research to streamline focus on specific brands, as they may get different results. Secondly, the respondents were controlled based on only being members of an SMBC; future research can also put more restriction based on nationality, age or location so as to get more insight into the behaviors of SMBC members. Finally, this study also adopted composite measurements for the behavioural aspect of consumer engagement variables, whereas future studies can measure other aspects (cognitive and emotional). 


\section{Conclusions}

The study provided theoretical and empirical evidence in ensuring the sustainability of SMBCs by investigating the relationship existing between FOMO, SPU, CE and L. The results derived from the study showed FOMO has a positive impact on SPU, CE and L. SPU also mediated the relationship between FOMO and $\mathrm{CE}$. This shows that FOMO and smartphones are of importance to firms with SMBCs, as it helps in securing the loyalty and ensuring CE in SMBC. These findings are significant and contribute to the body of knowledge in marketing, such that brand social media marketing can be geared more in creating more rewarding and interactive activities that will ultimately attract individuals to become loyal members of the brand's community. We suggest that brands with SMBCs should pay vital attention to the activities on the platform, especially the reactions of community members to brand posts, in order to monitor the type of posts that will generate high interactivity on the platform and capitalize on such posts to make sure their SMBC platform becomes a space that will constantly attract visitors, passive and active members.

Author Contributions: Conceptualization, O.S.O. and M.A.; methodology, O.S.O.; writing-original draft preparation, O.S.O.; writing-review and editing, M.A.; supervision, M.A.; All authors have read and agreed to the published version of the manuscript.

Funding: This research received no external funding.

Conflicts of Interest: The authors declare no conflicts of interest.

\section{Appendix A}

Table A1. Construct Measurement Items.

\begin{tabular}{|c|c|c|}
\hline Constructs & Items & Sources \\
\hline Fear of Missing Out & $\begin{array}{l}\text { I fear other consumers have more rewarding experiences } \\
\text { than me on this brand's fan page. } \\
\text { I get worried when I find other consumers are having fun } \\
\text { without me on this brand's fan page. } \\
\text { I get anxious when I don't know what other consumers are } \\
\text { up to on this brand's fan page. } \\
\text { When I have a brand related experience, it is important for } \\
\text { me to share the details on this brand's fan page. }\end{array}$ & [10] \\
\hline Smartphone Use & $\begin{array}{l}\text { I use my smartphone to visit this brand's fan page. } \\
\text { I use my smartphone to participate in activities on this } \\
\text { brand's fan page. } \\
\text { I use my smartphone to obtain information about this brand } \\
\text { on this brand's fan page. } \\
\text { I use my smartphone to get up to date brand related } \\
\text { information on this brand's fan page. }\end{array}$ & [51] \\
\hline $\begin{array}{l}\text { Consumer Engagement in } \\
\text { SMBC }\end{array}$ & $\begin{array}{l}\text { When online on Facebook, I usually participate in activities } \\
\text { on this brand's fan page. } \\
\text { When I engage in this brand's fan page, I read other peoples } \\
\text { comment and conversations. } \\
\text { I like, share and comment on post from this brand's fan page. } \\
\text { I spend a lot of time participating in activities on this brand's } \\
\text { fan page, compared to other brand pages. }\end{array}$ & [4] \\
\hline SMBC Loyalty & $\begin{array}{l}\text { I will frequently re-participate in activities of this brand's fan } \\
\text { page in the future. } \\
\text { I intend to revisit this brand's fan page. } \\
\text { I would recommend this brand's fan page to my } \\
\text { friends/relatives. } \\
\text { I will hardly consider switching to another brand's fan page }\end{array}$ & {$[42,61]$} \\
\hline
\end{tabular}




\section{References}

1. Ahmad, S.N.; Laroche, M. Analyzing electronic word of mouth: A social commerce construct. Int. J. Inf. Manag. 2017, 37, 202-213. [CrossRef]

2. Bazi, S.; Hajli, A.; Hajli, N.; Shanmugam, M.; Lin, X. Winning engaged consumers: The rules of brand engagement and intention of co-creation in social commerce. Inf. Technol. People 2019, 33, 456-476. [CrossRef]

3. Islam, J.U.; Rahman, Z.; Hollebeek, L.D. Consumer engagement in online brand communities: A solicitation of congruity theory. Internet Res. 2018, 28, 23-45. [CrossRef]

4. Liu, L.; Lee, M.K.O.; Liu, R.; Chen, J. International Journal of Information Management Trust transfer in social media brand communities: The role of consumer engagement. Int. J. Inf. Manag. 2018, 41, 1-13. [CrossRef]

5. Kaur, H.; Paruthi, M.; Islam, J.; Hollebeek, L.D. Online Consumer Brand Engagement on Virtual Brand Communities: The Role of Brand Community Identification and Rewards Harsandaldeep Kaur * Mandakini Paruthi ** JamidUl Islam ***. Telemat. Inform. 2019, 46, 101321. [CrossRef]

6. Islam, J.; Rahman, Z. The impact of online brand community characteristics on customer engagement: An application of Stimulus-Organism-Response paradigm. Telemat. Inform. 2017, 34, 96-109. [CrossRef]

7. Gómez, M.; Lopez, C.; Molina, A. An integrated model of social media brand engagement. Comput. Hum. Behav. 2019, 96, 196-206. [CrossRef]

8. Kaur, P.; Dhir, A.; Rajala, R.; Dwivedi, Y. Why people use online social media brand communities: A consumption value theory perspective. Online Inf. Rev. 2018, 42, 205-221. [CrossRef]

9. Cheung, C.M.K.; Lee, M.K.O. Understanding the sustainability of a virtual community: Model development and empirical test. J. Inf. Sci. 2009, 35, 279-298. [CrossRef]

10. Przybylski, A.K.; Murayama, K.; Dehaan, C.R.; Gladwell, V. Motivational, emotional, and behavioral correlates of fear of missing out. Comput. Hum. Behav. 2013, 29, 1841-1848. [CrossRef]

11. Rozgonjuk, D.; Elhai, J.D.; Ryan, T.; Scott, G.G. Computers \& Education Fear of missing out is associated with disrupted activities from receiving smartphone noti fi cations and surface learning in college students. Comput. Educ. 2019, 140, 103590.

12. Sha, P.; Sariyska, R.; Riedl, R.; Lachmann, B.; Montag, C. Addictive Behaviors Reports Linking Internet Communication and Smartphone Use Disorder by taking a closer look at the Facebook and WhatsApp applications is. Addict. Behav. Rep. 2019, 9, 100148. [CrossRef] [PubMed]

13. Taylor, D.G. Social Media Usage, FOMO, and Conspicuous Consumption: An Exploratory Study: An Abstract. In Academy of Marketing Science World Marketing Congress; Springer: Cham, Switzerland, 2018.

14. Bock, G.W.; Ahuja, M.K.; Suh, A.; Yap, L.X. Sustainability of a virtual community: Integrating individual and structural dynamics. J. Assoc. Inf. Syst. 2015, 16, 3. [CrossRef]

15. Fachrunnisa, O. Towards sustainability of virtual business community through trustworthy behaviour-based mechanism. Int. J. Web Based Communities 2016, 12, 296-322. [CrossRef]

16. Alt, D. College students' academic motivation, media engagement and fear of missing out. Comput. Hum. Behav. 2015, 49, 111-119. [CrossRef]

17. Gombert, L.; Rivkin, W.; Kleinsorge, T. A diary-study on work-related smartphone use and employees' well-being: The moderating role of basic need satisfactionArbeitsbezogene Smartphone-Nutzung und psychisches Wohlbefinden: Die moderierende Rolle der Befriedigung psychologischer Grundbedürfnisse. Z. Arb. 2018, 72, 111-119.

18. Kang, S.; Jung, J. Mobile communication for human needs: A comparison of smartphone use between the US and Korea. Comput. Hum. Behav. 2014, 35, 376-387. [CrossRef]

19. Elhai, J.D.; Yang, H.; Fang, J.; Bai, X.; Hall, B.J. Depression and anxiety symptoms are related to problematic smartphone use severity in Chinese young adults: Fear of missing out as a mediator. Addict. Behav. 2020, 101, 105962. [CrossRef]

20. Zeithaml, V.A.; Berry, L.L.; Parasuraman, A. The behavioral consequences of service quality. J. Mark. 1996, 60, 31-46. [CrossRef]

21. Popp, B.; Wilson, B. Computers in Human Behavior Investigating the role of identi fi cation for social networking Facebook brand pages. Comput. Hum. Behav. 2018, 84, 141-152. [CrossRef]

22. van Asperen, M.; de Rooij, P.; Dijkmans, C. Engagement-Based Loyalty: The Effects of Social Media Engagement on Customer Loyalty in the Travel Industry Engagement-Based Loyalty: The Effects of Social Media. Int. J. Hosp. Tour. Adm. 2018, 19, 78-94. 
23. Potgieter, L.M.; Naidoo, R. Factors explaining user loyalty in a social media-based brand community. S. Afr. J. Inf. Manag. 2017, 19, 1-9. [CrossRef]

24. Lin, C.P. Learning virtual community loyalty behavior from a perspective of social cognitive theory. Int. J. Hum. Comput. Interact. 2010, 26, 345-360. [CrossRef]

25. Tomczyk, Ł.; Selmanagic-lizde, E. Children and Youth Services Review Fear of Missing Out ( FOMO ) among youth in Bosnia and Herzegovina-Scale and selected mechanisms. Child. Youth Serv. Rev. 2018, 88, 541-549. [CrossRef]

26. Chambers, K.J. College Students' Anxiety, Social Media Engagement, and Fear of Missing Out. Ph.D. Thesis, William James College, Newton, MA, USA, 2018.

27. Alt, D.; Boniel-Nissim, M. Links between Adolescents' Deep and Surface Learning Approaches, Problematic Internet Use, and Fear of Missing Out (FoMO). Internet Interv. 2018, 13, 30-39. [CrossRef]

28. Alt, D. Students' Wellbeing, Fear of Missing out, and Social Media Engagement for Leisure in Higher Education Learning Environments. Curr. Psychol. 2018, 37, 128-138. [CrossRef]

29. Riordan, B.C.; Flett, J.A.M.; Hunter, J.A.; Scarf, D.; Conner, T.S. Fear of missing out (FoMO): The relationship between FoMO, alcohol use, and alcohol-related consequences in college students. J. Psychiatry Brain Funct. 2015, 2, 9. [CrossRef]

30. Keller, K.L. Conceptualizing, Measuring, and Managing Customer-Based Brand Equity. J. Mark. 1993, 57, 1-22. [CrossRef]

31. Grassl, W. Strategic Brand Management: Building, Measuring, and Managing Brand Equity. J. Consum. Mark. 2000, 12, 263-272. [CrossRef]

32. Yoshida, M.; Gordon, B.S.; Nakazawa, M.; Shibuya, S.; Fujiwara, N. Bridging the gap between social media and behavioral brand loyalty. Electron. Commer. Res. Appl. 2018, 28, 208-218. [CrossRef]

33. Barger, V.; Peltier, J.W.; Schultz, D.E. Social media and consumer engagement: A review and research agenda. J. Res. Interact. Mark. 2016, 10, 268-287. [CrossRef]

34. Rosen, L.D.; Carrier, L.M.; Pedroza, J.A.; Elias, S.; O’Brien, K.M.; Lozano, J.; Kim, K.; Cheever, N.A.; Bentley, J.; Ruiz, A. The role of executive functioning and technological anxiety (FOMO) in college course performance as mediated by technology usage and multitasking habits. Psicol. Educ. 2018, 24, 14-25. [CrossRef]

35. Wang, P.; Wang, X.; Nie, J.; Zeng, P.; Liu, K.; Wang, J.; Guo, J.; Lei, L. Envy and problematic smartphone use: The mediating role of FOMO and the moderating role of student-student relationship. Personal. Individ. Differ. 2019, 146, 136-142. [CrossRef]

36. Kneidinger-Müller, B. When the smartphone goes offline: A factorial survey of smartphone users' experiences of mobile unavailability. Comput. Hum. Behav. 2019, 98, 1-10. [CrossRef]

37. Wells, T.; Bailey, J.T.; Link, M.W. Comparison of Smartphone and Online Computer Survey Administration. Soc. Sci. Comput. Rev. 2014, 32, 238-255. [CrossRef]

38. Cho, J. Roles of Smartphone App Use in Improving Social Capital and Reducing Social Isolation. Cyberpsychol. Behav. Soc. Netw. 2015, 18, 350-355. [CrossRef]

39. Elhai, J.D.; Levine, J.C.; Alghraibeh, A.M.; Alafnan, A.A.; Aldraiweesh, A.A.; Hall, B.J. Fear of missing out: Testing relationships with negative affectivity, online social engagement, and problematic smartphone use. Comput. Hum. Behav. 2018, 89, 289-298. [CrossRef]

40. Wolniewicz, C.A.; Tiamiyu, M.F.; Weeks, J.W.; Elhai, J.D. Problematic smartphone use and relations with negative affect, fear of missing out, and fear of negative and positive evaluation. Psychiatry Res. 2018, 262, 618-623. [CrossRef]

41. Chung, Y.; Jiyoung, A. Effects of mergers and acquisitions on brand loyalty in luxury Brands: The moderating roles of luxury tier di ff erence and social media. J. Bus. Res. 2019. [CrossRef]

42. Hsu, C.; Lu, H. Consumer behavior in online game communities: A motivational factor perspective. Comput. Hum. Behav. 2007, 23, 1642-1659. [CrossRef]

43. Brodie, R.J.; Ilic, A.; Juric, B.; Hollebeek, L. Consumer engagement in a virtual brand community: An exploratory analysis. J. Bus. Res. 2013, 66, 105-114. [CrossRef]

44. Vivek, S.D.; Beatty, S.E.; Morgan, R.M.; Vivek, S.D.; Beatty, S.E.; Customer, R.M.M. Customer Engagement: Exploring Customer Relationships Beyond Purchase Customer Engagement: Exploring Customer Relationships Beyond Purchase. J. of Mkt. Pract 2014, 6679, 122-146.

45. Pasternak, O.; Veloutsou, C.; Morgan-Thomas, A. Self-presentation, privacy and electronic word-of-mouth in social media. J. Prod. Brand Manag. 2017, 26, 415-428. [CrossRef] 
46. Kim, J.; Lee, K.H. Influence of integration on interactivity in social media luxury brand communities. J. Bus. Res. 2019, 99, 422-429. [CrossRef]

47. Ruiz-Mafe, C.; Martí-Parreño, J.; Sanz-Blas, S. Key drivers of consumer loyalty to Facebook fan pages. Online Inf. Rev. 2014, 38, 362-380. [CrossRef]

48. Wiese, M.; Akareem, H.S. Friends with benefits: Can firms benefit from consumers' sense of community in brand Facebook pages? Eur. Bus. Rev. 2019, 31, 947-969. [CrossRef]

49. Tan, W.K.; Lu, K.J. Smartphone use at tourist destinations: Interaction with social loneliness, aesthetic scope, leisure boredom, and trip satisfaction. Telemat. Inform. 2019, 39, 64-74. [CrossRef]

50. Khan, M.L. Social media engagement: What motivates user participation and consumption on YouTube? Comput. Human Behav. 2017, 66, 236-247. [CrossRef]

51. Zhou, Z.; Zhang, Q.; Su, C.; Zhou, N. How do brand communities generate brand relationships? Intermediate mechanisms. J. Bus. Res. 2012, 65, 890-895. [CrossRef]

52. Hair, J.F.; Ringle, C.M.; Sarstedt, M. PLS-SEM: Indeed a silver bullet. J. Mark. Theory Pract. 2011, 19, $139-151$. [CrossRef]

53. Harmeling, C.M.; Moffett, J.W.; Arnold, M.J.; Carlson, B.D. Toward a theory of customer engagement marketing. J. Acad. Mark. Sci. 2017, 45, 312-335. [CrossRef]

54. Hair, J.F., Jr.; Black, W.C.; Babin, B.J.; Anderson, R.E. Multivariate Data Analysis, 7th ed.; Pearson Education Inc.: Upper saddle River, NJ, USA, 2010.

55. Fornell, C.; Larcker, D.F. Evaluating Structural Equation Models with Unobservable Variables and Measurement Error. J. Mark. Res. 1981, 18, 39-50. [CrossRef]

56. Podsakoff, P.M.; Organ, D.W. Self-Reports in Organizational Research: Problems and Prospects. J. Manag. 1986, 12, 531-544. [CrossRef]

57. Alt, D. Students' social media engagement and fear of missing out (FoMO) in a diverse classroom. J. Comput. High. Educ. 2017, 29, 388-410. [CrossRef]

58. Alt, D. College students' perceived learning environment and their social media engagement in activities unrelated to class work. Instr. Sci. 2017, 45, 623-643. [CrossRef]

59. Turkle, S. Alone Together: Why We Expect More from Technology and Less from Each Other? Basic Books: New York, NY, USA, 2017.

60. Woisetschlager, D.M.; Hartleb, V.; Blut, M. How to make brand communities work: Antecedents and consequences of consumer participation. J. Relat. Mark. 2008, 7, 237-256. [CrossRef]

61. Algesheimer, R.; Dholakia, U.M.; Herrmann, A. The social influence of brand community: Evidence from European car clubs. J. Mark. 2005, 69, 19-34. [CrossRef]

62. Wu, H.; Xiao, T.; Wu, X. More is better? The influencing of user involvement on user loyalty in online travel community. Asia Pacific J. Tour. Res. 2017, 22, 357-369. [CrossRef]

63. Khan, I.; Rahman, Z.; Fatma, M. The role of customer brand engagement and brand experience in online banking. Int. J. Bank Mark. 2016, 34, 1025-1041. [CrossRef]

64. Islam, J.U.; Rahman, Z. Linking Customer Engagement to Trust and Word-of-Mouth on Facebook Brand Communities: An Empirical Study. J. Internet Commer. 2016, 15, 40-58. [CrossRef]

65. Bitter, S.; Grabner-Kräuter, S. Consequences of customer engagement behavior: When negative Facebook posts have positive effects. Electron. Mark. 2016, 26, 219-231. [CrossRef]

66. Rozgonjuk, D.; Kattago, M.; Täht, K. Computers in Human Behavior Social media use in lectures mediates the relationship between procrastination and problematic smartphone use. Comput. Hum. Behav. 2018, 89, 191-198. [CrossRef]

67. Zhao, Z.; Balagué, C. Designing branded mobile apps: Fundamentals and recommendations. Bus. Horiz. 2015, 58, 305-315. [CrossRef]

68. Gill, M.; Sridhar, S.; Grewal, R. Return on engagement initiatives: A study of a business-to-business mobile app. J. Mark. 2017, 81, 45-66. [CrossRef]

(C) 2020 by the authors. Licensee MDPI, Basel, Switzerland. This article is an open access article distributed under the terms and conditions of the Creative Commons Attribution (CC BY) license (http://creativecommons.org/licenses/by/4.0/). 